\title{
Clinical Trial Site Training Completion Document
}

National Cancer Institute

\section{Source}

National Cancer Institute. Clinical Trial Site Training Completion Document. NCI

Thesaurus. Code C115674.

Records that verify completion of clinical trial site training for the site medical investigator and his/her staff. 